\title{
Endoscopic features aiding the diagnosis of gastric mucosa-associated lymphoid tissue lymphoma
}

\author{
Byung Sam Park, Si Hyung Lee \\ Division of Gastroenterology and Hepatology, Department of Internal Medicine, Yeungnam University College of Medicine, Daegu, Korea
}

Received: December 28, 2018

Revised: January 25, 2019

Accepted: February 18, 2019

Corresponding author:

Si Hyung Lee

Division of Gastroenterology and

Hepatology, Department of

Internal Medicine, Yeungnam

University College of Medicine,

170, Hyeonchung-ro, Nam-gu,

Daegu 42415, Korea

Tel: +82-53-620-3830

Fax: +82-53-623-8038

E-mail:dr9696@gmail.com
The incidence of gastric mucosa-associated lymphoid tissue (MALT) lymphoma is increasing worldwide, but the diagnosis is difficult. Most patients are asymptomatic or complain of nonspecific gastrointestinal symptoms. As the endoscopic features of gastric MALT lymphoma are variable and nonspecific, the possibility of this condition may be overlooked during esophagogastroduodenoscopy, and it remain undiagnosed. Therefore, this condition needs to be considered when an abnormal mucosa is observed during this procedure. Biopsy performed during endoscopy is the primary diagnostic test, but false negative results are possible; large numbers of samples should be collected from both normal and abnormal mucosae. Endoscopic ultrasonography is useful to assess the depth of invasion and to predict the treatment response. After treatment, follow-up tests are required every 3 months until complete remission is achieved, and annually thereafter. Early diagnosis of gastric MALT lymphoma is difficult, and its diagnosis and follow-up require wide experience and competent endoscopic technique.

Keywords: Diagnosis; Follow-up studies; Gastrointestinal endoscopy; Marginal zone B-cell lymphoma; Stomach neoplasms

\section{Introduction}

Primary gastric lymphoma is the most common extranodal lymphoma, accounting for $2-7 \%$ of gastric malignancies [1]. Histologically, mucosal-associated lymphoid tissue (MALT) lymphoma accounts for approximately $40 \%$ of primary gastric lymphoma, and diffuse large B-cell lymphoma accounts for most of the remainder $[2,3]$. MALT lymphoma accounts for $5-8 \%$ of B-cell lymphomas and may occur in the entire digestive system, but most commonly in the upper gastrointestinal tract $[4,5]$. MALT lymphoma was first reported by Isaacson and Wright in 1983 [6] and classified as a B-marginal zone lymphoma and extranodal type in the Revised European American Lymphoma classification in 1994. In 2008, the World Health Organization classification showed extranodal marginal zone B-cell lymphoma of MALT.
Helicobacter pylori (H. pylori) infection is closely related to the development of gastric MALT lymphoma and is associated with $90 \%$ of gastric MALT lymphoma $[7,8]$. H. pylori eradication therapy can induce complete remission of low-grade gastric MALT lymphoma in $80 \%$ of patients, and favorable long-term prognosis had been shown [9-11]. However, most patients with gastric MALT lymphoma are asymptomatic or complain of nonspecific gastrointestinal symptoms, and the endoscopic features of gastric MALT lymphoma are variable and nonspecific, making it difficult to distinguish from gastritis, erosion, benign gastric ulcer, and gastric cancer [12]. In addition, the time until remission of gastric MALT lymphoma after $H$. pylori eradication therapy may be long [13], and recognition of remission is difficult because of atrophied and discolored mucosa. Therefore, diagnosis and follow-up of gastric MALT lymphoma require wide experience and competent

Copyright@ 2019 Yeungnam University College of Medicine

This is an Open Access article distributed under the terms of the Creative Commons Attribution Non-Commercial License (http://creativecommons.org/licenses/by-nc/4.0/) which permits unrestricted non-commercial use, distribution, and reproduction in any medium, provided the original work is properly cited. 
endoscopic technique. Here, we describe the diagnosis and followup of gastric MALT lymphoma with emphasis on endoscopic findings.

\section{Diagnosis of gastric MALT lymphoma}

\section{Esophagogastroduodenoscopy}

The endoscopic features of gastric MALT lymphoma can be classified into exophytic, ulceroinfiltrative, and superficial types; ulceroinfiltrative type is the most common, accounting for approximately 40-50\% of all cases [14-17]. Yokoi et al. categorized the superficial types of gastric MALT lymphoma into IIc-like, submucosal tumor, multiple erosion, cobblestone mucosa, partial fold-thickening, and discoloration types [18]. Gastric MALT lymphoma may be missed during esophagogastroduodenoscopy (EGD) because its endoscopic features are variable and nonspecific. Therefore, this condition needs to be considered when abnormal mucosa is observed during this procedure (Fig. 1).

Endoscopic biopsy using forcep and histopathologic examination are the most basic tests for diagnosis of gastric MALT lymphoma. However, false-negative results in the histologic examination may be possible because the tumor cell of gastric MALT lymphoma originates from the deep mucosa or submucosa and grows without destroying the foveolar gland, which is the basic structure of the mucosal surface $[19,20]$. Therefore, repeated EGD and endoscopic biopsy may be needed for accurate diagnosis of gastric MALT lymphoma. Furthermore, because gastric MALT lymphoma may have a multifocal distribution of tumors and high-
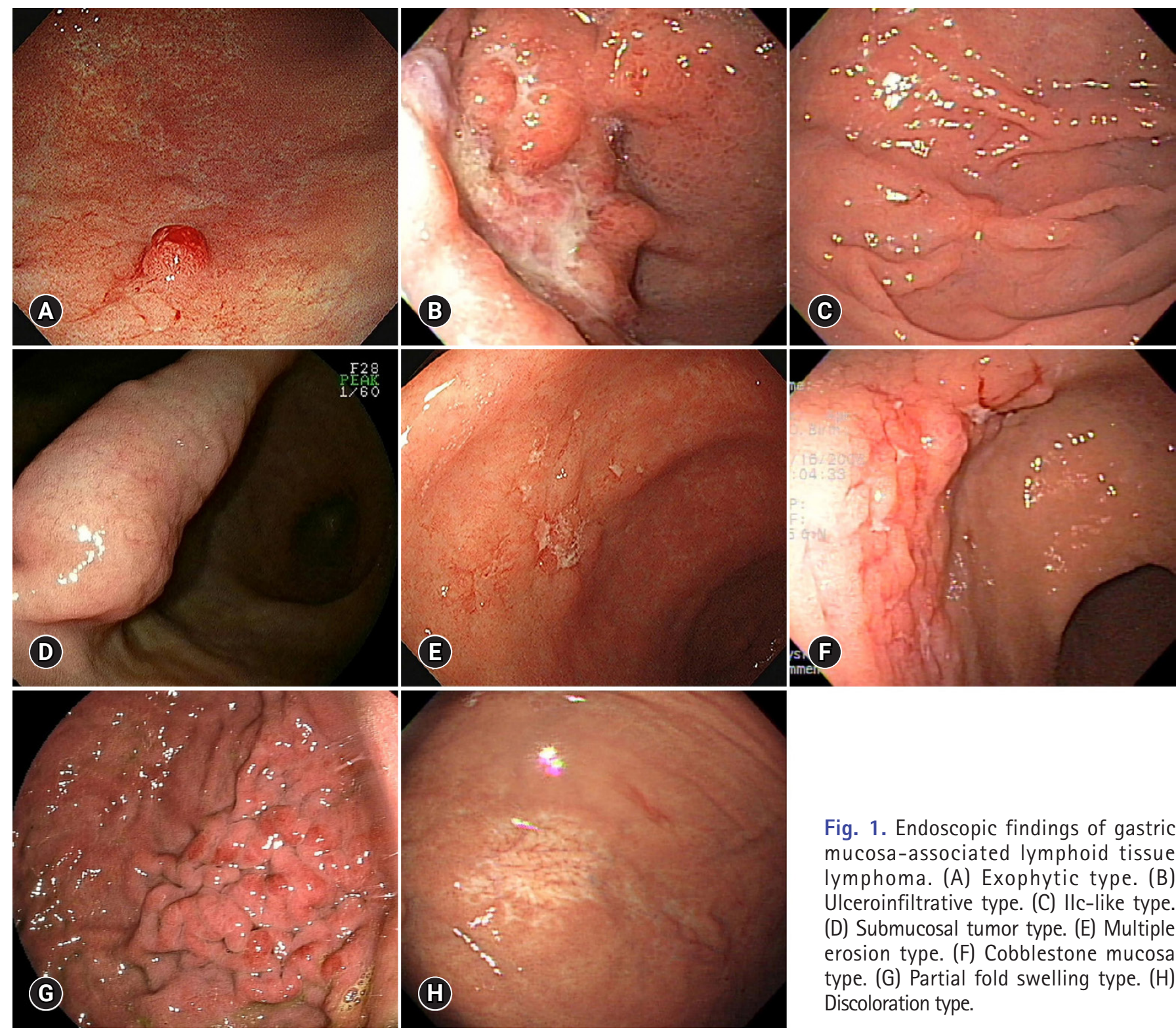

Fig. 1. Endoscopic findings of gastric mucosa-associated lymphoid tissue Iymphoma. (A) Exophytic type. (B) Ulceroinfiltrative type. (C) IIc-like type. (D) Submucosal tumor type. (E) Multiple erosion type. (F) Cobblestone mucosa type. (G) Partial fold swelling type. (H) Discoloration type. 
grade gastric MALT lymphoma may be present together, multiple endoscopic biopsies should be performed in the normal mucosa of the antrum, greater and lesser curvatures of the body, and fundus, as well as the abnormal mucosa of at least two tissues in each part [21]. More invasive tissue biopsy such as endoscopic mucosal resection (EMR) or endoscopic submucosal dissection (ESD) may be required if the diagnosis is not confirmed by endoscopic biopsy [22].

Lymphoepithelial lesion is characteristic feature of gastric MALT lymphoma. Wotherspoon et al. [23] proposed a histological classification system to differentiate normal gastric mucosa and gastric MALT lymphoma (Table 1). Gastric MALT lymphoma can be diagnosed if a histopathologic change corresponding to a score of 5 is observed. If the score is 3 or 4 , diagnosis is confirmed based on the monoclonality of B-cells in polymerase chain reaction (PCR) [24]. In addition to morphological evaluation of the tissues, immunohistochemical staining of cluster of differentiation (CD) 20, CD79a, CD43, and more can be performed to diagnose gastric MALT lymphoma. A balanced translocation, $\mathrm{t}(11 ; 18)$ (q21;q21), is found in 25-30\% of gastric MALT lymphoma cases [25], and it was shown to be associated with a low response to $H$. pylori eradication therapy and poor prognosis [26,27]. Moreover, $\mathrm{t}(11 ; 18)(\mathrm{q} 21 ; \mathrm{q} 21)$ assessed by fluorescence in situ hybridization or API2/MALT1 fusion gene, which is the result of chromosomal translocation, detected by reverse transcriptase PCR, can identify the patients who are expected to have low therapeutic response to H. pylori eradication therapy.

Table 1. Wotherspoon histologic scoring system for diagnosis of MALT Iymphoma [23]

\begin{tabular}{|c|c|c|}
\hline Score & Diagnosis & Histologic features \\
\hline 0 & Normal & $\begin{array}{l}\text { Scattered plasma cells in lamina propria. } \\
\text { No lymphoid follicles }\end{array}$ \\
\hline 1 & $\begin{array}{l}\text { Chronic active } \\
\text { gastritis }\end{array}$ & $\begin{array}{l}\text { Small clusters of lymphocytes in } \\
\text { lamina propria. No lymphoid follicles. } \\
\text { No lymphoepithelial lesions }\end{array}$ \\
\hline 2 & $\begin{array}{l}\text { Chronic active gastritis } \\
\text { with florid lymphoid } \\
\text { follicle formation }\end{array}$ & $\begin{array}{l}\text { Prominent lymphoid follicles with } \\
\text { surrounding mantle zone and plasma } \\
\text { cells. No lymphoepithelial lesions }\end{array}$ \\
\hline 3 & $\begin{array}{l}\text { Suspicious lymphoid } \\
\text { infiltrate, favor } \\
\text { reactive }\end{array}$ & $\begin{array}{l}\text { Lymphoid follicles surrounded by small } \\
\text { lymphocytes that infiltrate diffusely in } \\
\text { lamina propria and occasionally into } \\
\text { epithelium }\end{array}$ \\
\hline 4 & $\begin{array}{l}\text { Suspicious lymphoid } \\
\text { infiltrate, favor } \\
\text { lymphoma }\end{array}$ & $\begin{array}{l}\text { Lymphoid follicles surrounded by marginal } \\
\text { zone cells that infiltrate diffusely in } \\
\text { lamina propria and into epithelium in } \\
\text { small groups }\end{array}$ \\
\hline 5 & MALT Iymphoma & $\begin{array}{l}\text { Dense diffuse lamina propria infiltrate } \\
\text { of marginal zone cells with prominent } \\
\text { lymphoepithelial lesions }\end{array}$ \\
\hline
\end{tabular}

MALT, mucosa-associated lymphoid tissue.
Confirming $H$. pylori infection in gastric MALT lymphoma is important because the presence of $H$. pylori affects treatment strategy and response. $H$. pylori infection must be detected by rapid urease test, histological examination, culture test, urea breath test, and stool antigen test [28], and the presence of $H$. pylori should be confirmed during the histopathologic evaluation for the diagnosis of gastric MALT lymphoma. Because hematoxylin and eosin staining has low sensitivity for $H$. pylori diagnosis and has difficulty in detecting non-spiral and spherical $H$. pylori, special stainings, such as Giemsa, Warthin-Starry, and Alcian blue, or immunostaining for $H$. pylori, which is the most sensitive and specific, may be required to confirm $H$. pylori infection $[29,30]$.

Recently, several studies have been reported to improve the diagnosis of gastric MALT lymphoma by using imaging-enhanced endoscopy, such as narrow-band imaging or linked color imaging $[31,32]$.

\section{Endoscopic ultrasonography}

Endoscopic ultrasonography (EUS), which has sensitivity of $89 \%$, a specificity of $97 \%$, and a total accuracy of $97 \%$, is the most accurate test to assess the depth of tumor invasion of gastric MALT lymphoma $[33,34]$. EUS is also useful for evaluating local lymph node metastasis. EUS findings of gastric MALT lymphoma can be classified into four types: superficially spreading, diffusely infiltrating, mass forming, and mixed. Superficially spreading and diffusely infiltrating types are seen in low-grade gastric MALT lymphoma, and tumor invasion into the whole gastric wall and lymph node enlargement are characteristics of high-grade gastric MALT lymphoma [35].

EUS can be used to diagnose gastric MALT lymphoma. A thickened gastric wall of 6-12 $\mathrm{mm}$ in the EUS can predict gastric MALT lymphoma, and EUS-guided fine needle aspiration (EUS-FNA) can provide diagnostic information by securing false negatives that may occur in endoscopic biopsy [36,37].

EUS can help predict the treatment response of gastric MALT lymphoma. When the gastric MALT lymphoma infiltrates into the submucosal layer in EUS, the complete remission rate for $H$. pylori eradication therapy is lower than that for the mucosal layer. When the tumor invades the muscle layer, complete remission was not achieved by $H$. pylori eradication therapy [38,39] (Fig. 2).

After the treatment of gastric MALT lymphoma, therapeutic response or relapse after the remission could be evaluated by tracking the changes in the gastric wall thickness by EUS [40]. However, even when remission is achieved, normalization of the thickened gastric wall occurs slowly, and EUS may show normal findings even if the tumor remains histologically [41]. Nevertheless, if thickened stomach wall is observed on EUS even 

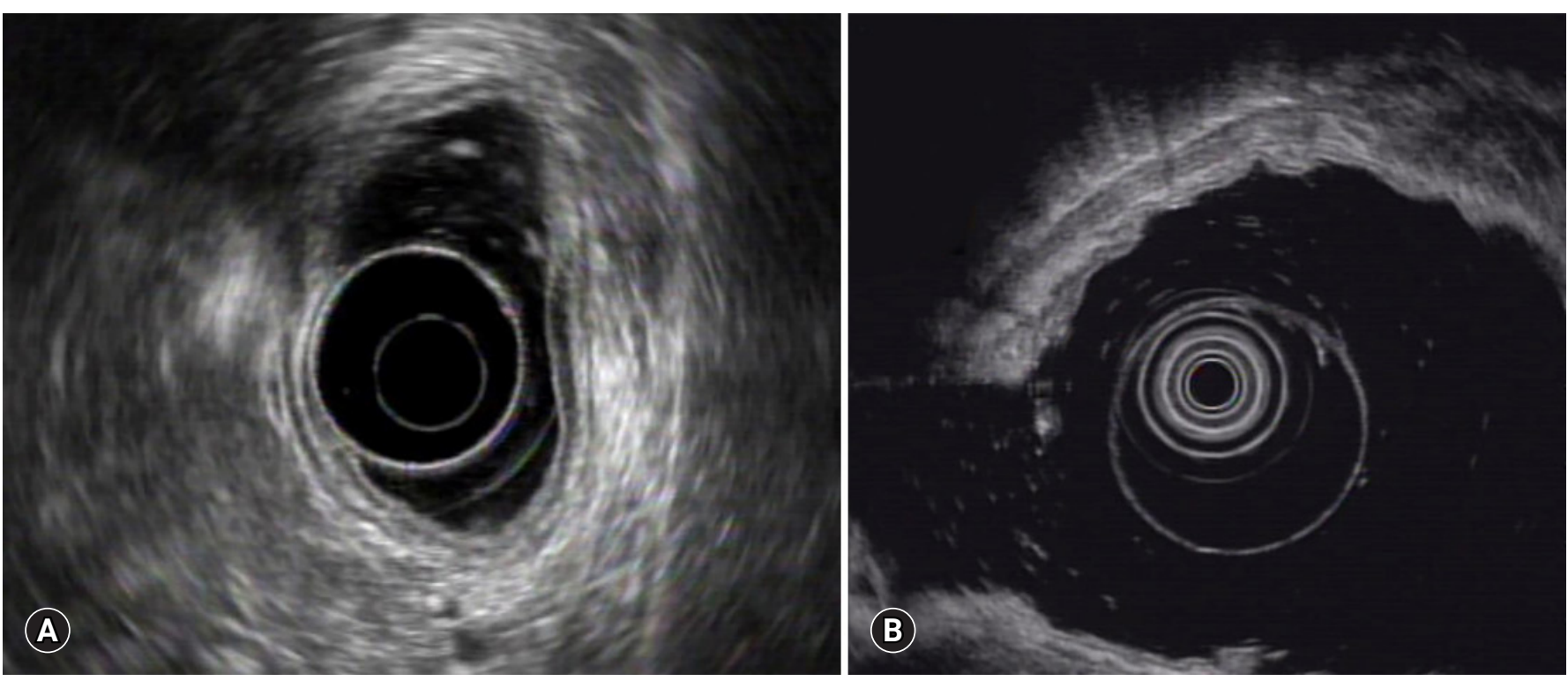

Fig. 2. Endoscopic ultrasonography findings of gastric mucosa-associated lymphoid tissue lymphoma. (A) Tumor limited to the mucosa. (B) Tumor invading the submucosa.

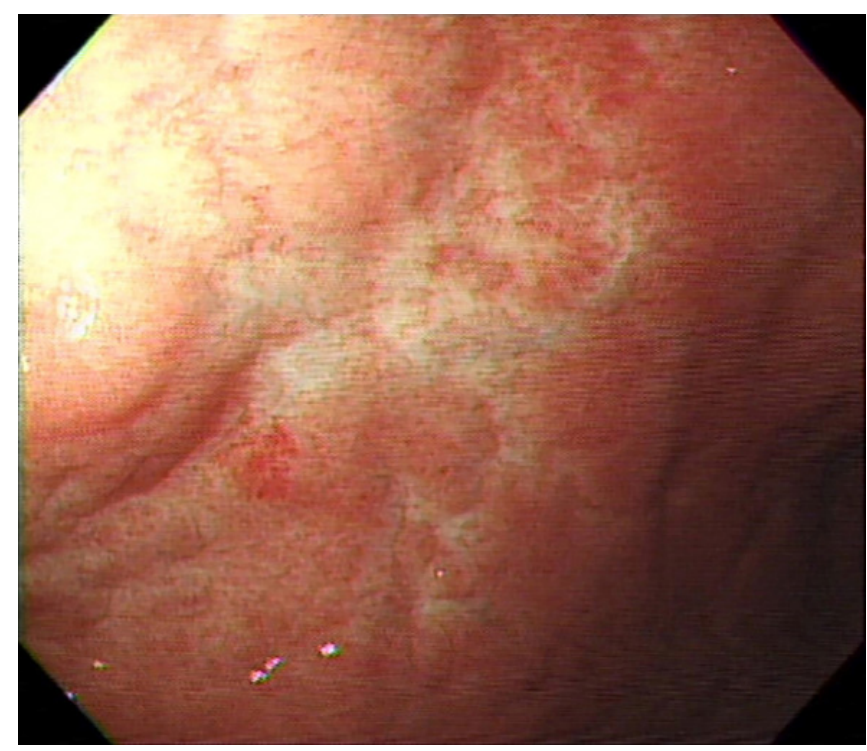

Fig. 3. Endoscopic findings of gastric MALT lymphoma after treatment. Mucosa, which was diagnosed as MALT lymphoma, had changed to atrophic and whitish discolored mucosa after Helicobacter pylori eradication. MALT, mucosa-associated lymphoid tissue.

after sufficient time has elapsed since treatment of gastric MALT lymphoma, the possibility of residual gastric MALT lymphoma cannot be ruled out, albeit normal histopathologic examination results [35].

\section{Follow-up of gastric MALT lymphoma}

Complete remission of gastric MALT lymphoma can be achieved at $80-86 \%$ by $H$. pylori eradication therapy $[42,43]$. H. pylori eradication therapy is also considered as a primary treatment option for $H$. pylori-negative gastric MALT lymphoma [44]. $H$. pylori eradication was confirmed at least 4 weeks after $H$. pylori eradication therapy, and follow-up test with EGD, histology, and EUS were performed every 3 months until complete remission was achieved. Complete remission after $H$. pylori eradication therapy is slow and may take more than a year in some cases [45]. The number of tumor cells is decreased after $H$. pylori eradication therapy; hence, a sufficient amount of biopsy specimens must be obtained. Complete remission can be determined if histologic remission is identified in two consecutive biopsy results.

After remission, lesions of gastric MALT lymphoma changed to atrophic and whitish discolored mucosa [46] (Fig. 3). Recovery of gastric pit and microvascular structures, which were destroyed and disappeared, can be seen on magnifying endoscopy [47]. The whitish discolored mucosa with definite vascular network showed no recurrence after remission, but the granular mucosa without definite vascular network more likely recurs after remission [48].

After remission, gastric MALT lymphoma can recur regardless of $H$. pylori reinfection, and it has a long-term recurrence rate of $7-8 \%$, and the recurrence rate is $2.2 \%$ annually $[9,42]$. Because the risk of developing metachronous gastric adenocarcinoma is increased and this risk persists after several years in patients with gastric MALT lymphoma [49], annual follow-up EGD is recommended after remission of gastric MALT lymphoma. However, there is a lack of studies about how long follow-up EGD should be performed. Because the endoscopic findings of recurred 
gastric MALT lymphoma are non-specific and variable, sufficient biopsies at multiple sites must be performed.

\section{Conclusion}

The early diagnosis of gastric MALT lymphoma is difficult because its symptoms and endoscopic findings are nonspecific. Therefore, if an abnormal mucosa is observed during EGD, gastric MALT lymphoma should be considered, and multiple biopsies and EUS should be performed. In addition, the possibility of falsenegative results of endoscopic biopsy should be considered, and more invasive tissue biopsy, such as EUS-FNA, EMR, and ESD, may be necessary. EUS can be used not only for diagnosis, but also for prediction of treatment response. Regular follow-up EGD and EUS are required after treatment of gastric MALT lymphoma.

\section{Acknowledgements}

This work was supported by a grant from Chunma Medical Research Foundation, Korea, 2017.

\section{Conflicts of interest}

No potential conflicts of interest relevant to this article was reported.

\section{ORCID}

Byung Sam Park, https://orcid.org/0000-0002-5970-0947

Si Hyung Lee, https://orcid.org/0000-0001-7221-7506

\section{References}

1. Doglioni C, Wotherspoon AC, Moschini A, de Boni M, Isaacson PG. High incidence of primary gastric lymphoma in northeastern Italy. Lancet 1992;339:834-5.

2. Papaxoinis G, Papageorgiou S, Rontogianni D, Kaloutsi V, Fountzilas G, Pavlidis N, et al. Primary gastrointestinal nonHodgkin's lymphoma: a clinicopathologic study of 128 cases in Greece. A Hellenic Cooperative Oncology Group study (HeCOG). Leuk Lymphoma 2006;47:2140-6.

3. Ferrucci PF, Zucca E. Primary gastric lymphoma pathogenesis and treatment: what has changed over the past 10 years? $\mathrm{Br} J$ Haematol 2007;136:521-38.

4. Armitage JO. A clinical evaluation of the International Lymphoma Study Group classification of non-Hodgkin's lymphoma. The Non-Hodgkin's Lymphoma Classification
Project. Blood 1997;89:3909-18.

5. Olszewski AJ, Castillo JJ. Survival of patients with marginal zone lymphoma: analysis of the Surveillance, Epidemiology, and End Results database. Cancer 2013;119:629-38.

6. Isaacson P, Wright DH. Malignant lymphoma of mucosaassociated lymphoid tissue. A distinctive type of B-cell lymphoma. Cancer 1983;52:1410-6.

7. Ruskoné-Fourmestraux A, Fischbach W, Aleman BM, Boot $\mathrm{H}, \mathrm{Du} \mathrm{MQ}$, Megraud F, et al. EGILS consensus report. Gastric extranodal marginal zone B-cell lymphoma of MALT. Gut 2011;60:747-58.

8. Zucca E, Copie-Bergman C, Ricardi U, Thieblemont C, Raderer M, Ladetto Met al. Gastric marginal zone lymphoma of MALT type: ESMO Clinical Practice Guidelines for diagnosis, treatment and follow-up. Ann Oncol 2013;24(Suppl 6):vi144-8.

9. Zullo A, Hassan C, Cristofari F, Andriani A, De Francesco V, Ierardi E, et al. Effects of Helicobacter pylori eradication on early stage gastric mucosa-associated lymphoid tissue lymphoma. Clin Gastroenterol Hepatol 2010;8:105-10.

10. Ono S, Kato M, Takagi K, Kodaira J, Kubota K, Matsuno Y, et al. Long-term treatment of localized gastric marginal zone B-cell mucosa associated lymphoid tissue lymphoma including incidence of metachronous gastric cancer. J Gastroenterol Hepatol 2010;25:804-9.

11. Nakamura S, Sugiyama T, Matsumoto T, Iijima K, Ono S, Tajika M, et al. Long-term clinical outcome of gastric MALT lymphoma after eradication of Helicobacter pylori: a multicentre cohort follow-up study of 420 patients in Japan. Gut 2012;61:507-13.

12. Kelessis NG, Vassilopoulos PP, Tsamakidis KG, Bai MG, Avital $\mathrm{S}$, Rosenthal RJ. Is gastroscopy still a valid diagnostic tool in detecting gastric MALT lymphomas? A dilemma beyond the eye. Mucosa-associated lymphoid tissue. Surg Endosc 2003;17:469-74.

13. Stathis A, Chini C, Bertoni F, Proserpio I, Capella C, Mazzucchelli L, et al. Long-term outcome following Helicobacter pylori eradication in a retrospective study of 105 patients with localized gastric marginal zone B-cell lymphoma of MALT type. Ann Oncol 2009;20:1086-93.

14. Taal BG, den Hartog Jager FC, Tytgat GN. The endoscopic spectrum of primary non-Hodgkin's lymphoma of the stomach. Endoscopy 1987;19:190-2.

15. Zucca E, Bertoni F, Roggero E, Cavalli F. The gastric marginal zone B-cell lymphoma of MALT type. Blood 2000;96:410-9.

16. Lee SK, Lee YC, Chung JB, Chon CY, Moon YM, Kang JK, et al. Low grade gastric mucosa associated lymphoid tissue lymphoma: treatment strategies based on 10 year follow-up. 
World J Gastroenterol 2004;10:223-6.

17. Aoun JP, Moukarbel N, Khoury S. Endoscopic patterns of primary gastric MALT lymphoma.J Med Liban 1998;46:131-5.

18. Yokoi T, Nakamura T, Nakamura S. Differential diagnosis of gastric MALT lymphomas. Stomach Intest 2001;36:13-20.

19. Caletti G, Barbara L. Gastric lymphoma: difficult to diagnose, difficult to stage? Endoscopy 1993;25:528-30.

20. Taal BG, Boot H, van Heerde P, de Jong D, Hart AA, Burgers JM. Primary non-Hodgkin lymphoma of the stomach: endoscopic pattern and prognosis in low versus high grade malignancy in relation to the MALT concept. Gut 1996;39:556-61.

21. Hu Q, Zhang Y, Zhang X, Fu K. Gastric mucosa-associated lymphoid tissue lymphoma and Helicobacter pylori infection: a review of current diagnosis and management. Biomark Res 2016;4:15.

22. Suekane H, Iida M, Kuwano Y, Kohrogi N, Yao T, Iwashita A, et al. Diagnosis of primary early gastric lymphoma. Usefulness of endoscopic mucosal resection for histologic evaluation. Cancer 1993;71:1207-13.

23. Wotherspoon AC, Doglioni C, Diss TC, Pan L, Moschini A, de Boni M, et al. Regression of primary low-grade B-cell gastric lymphoma of mucosa-associated lymphoid tissue type after eradication of Helicobacter pylori. Lancet 1993;342:575-7.

24. Hummel M, Oeschger S, Barth TF, Loddenkemper C, Cogliatti SB, Marx A, et al. Wotherspoon criteria combined with B cell clonality analysis by advanced polymerase chain reaction technology discriminates covert gastric marginal zone lymphoma from chronic gastritis. Gut 2006;55:782-7.

25. Du MQ, Atherton JC. Molecular subtyping of gastric MALT lymphomas: implications for prognosis and management. Gut 2006;55:886-93.

26. Liu H, Ruskon-Fourmestraux A, Lavergne-Slove A, Ye H, Molina T, Bouhnik Y, et al. Resistance of $t(11 ; 18)$ positive gastric mucosa-associated lymphoid tissue lymphoma to Helicobacter pylori eradication therapy. Lancet 2001;357:39-40.

27. Zullo A, Hassan C, Andriani A, Cristofari F, Cardinale V, Spinelli GP, et al. Primary low-grade and high-grade gastric MALT-lymphoma presentation. J Clin Gastroenterol 2010;44:340-4.

28. Malfertheiner P, Megraud F, O'Morain CA, Gisbert JP, Kuipers EJ, Axon AT, et al. Management of Helicobacter pylori infection-the Maastricht V/Florence Consensus Report. Gut 2017;66:6-30.

29. Hartman DJ, Owens SR. Are routine ancillary stains required to diagnose Helicobacter infection in gastric biopsy specimens? An institutional quality assurance review. Am J Clin Pathol
2012;137:255-60

30. Wang XI, Zhang S, Abreo F, Thomas J. The role of routine immunohistochemistry for Helicobacter pylori in gastric biopsy. Ann Diagn Pathol 2010;14:256-9.

31. Nonaka K, Ishikawa K, Arai S, Nakao M, Shimizu M, Sakurai $\mathrm{T}$, et al. A case of gastric mucosa-associated lymphoid tissue lymphoma in which magnified endoscopy with narrow band imaging was useful in the diagnosis. World J Gastrointest Endosc 2012;4:151-6.

32. Deng P, Min M, Ma CY, Liu Y. Linked color imaging technology for diagnosis of gastric mucosa-associated lymphoid tissue lymphoma. Chin Med J (Engl) 2017;130:2759-60.

33. Caletti G, Ferrari A, Brocchi E, Barbara L. Accuracy of endoscopic ultrasonography in the diagnosis and staging of gastric cancer and lymphoma. Surgery 1993;113:14-27.

34. Palazzo L, Roseau G, Ruskone-Fourmestraux A, Rougier P, Chaussade S, Rambaud JC, et al. Endoscopic ultrasonography in the local staging of primary gastric lymphoma. Endoscopy 1993;25:502-8.

35. Mehra M, Agarwal B. Endoscopic diagnosis and staging of mucosa-associated lymphoid tissue lymphoma. Curr Opin Gastroenterol 2008;24:623-6.

36. Lévy M, Hammel P, Lamarque D, Marty O, Chaumette MT, Haioun C, et al. Endoscopic ultrasonography for the initial staging and follow-up in patients with low-grade gastric lymphoma of mucosa-associated lymphoid tissue treated medically. Gastrointest Endosc 1997;46:328-33.

37. Queneau PE, Helg C, Brundler MA, Frossard JL, Spahr L, Girardet C, et al. Diagnosis of a gastric mucosa-associated lymphoid tissue lymphoma by endoscopic ultrasonographyguided biopsies in a patient with a parotid gland localization. Scand J Gastroenterol 2002;37:493-6.

38. El-Zahabi LM, Jamali FR, El-Hajj II, Naja M, Salem Z, Shamseddine A, et al. The value of EUS in predicting the response of gastric mucosa-associated lymphoid tissue lymphoma to Helicobacter pylori eradication. Gastrointest Endosc 2007;65:89-96.

39. Sheu BS, Shiesh SC, Wang JT, Yang HB, Lin ST, Wu JJ. Clinical application of $20 \mathrm{MHz}$ endosonography and antiHelicobacter pylori immunoblots to predict regression of low-grade gastric MALToma by H. pylori eradication. Helicobacter 2003;8:36-45.

40. Yeh HZ, Chen GH, Chang WD, Poon SK, Yang SS, Lien $\mathrm{HC}$, et al. Long-term follow up of gastric low-grade mucosaassociated lymphoid tissue lymphoma by endosonography emphasizing the application of a miniature ultrasound probe. J Gastroenterol Hepatol 2003;18:162-7. 
41. Janssen J. The impact of EUS in primary gastric lymphoma. Best Pract Res Clin Gastroenterol 2009;23:671-8.

42. Choi YJ, Lee DH, Kim JY, Kwon JE, Kim JY, Jo HJ, et al. Low grade gastric mucosa-associated lymphoid tissue lymphoma: clinicopathological factors associated with helicobacter pylori eradication and tumor regression. Clin Endosc 2011;44:101-8.

43. Ryu KD, Kim GH, Park SO, Lee KJ, Moon JY, Jeon HK, et al. Treatment outcome for gastric mucosa-associated lymphoid tissue lymphoma according to Helicobacter pylori infection status: a single-center experience. Gut Liver 2014;8:408-14.

44. Thieblemont C, Zucca E. Clinical aspects and therapy of gastrointestinal MALT lymphoma. Best Pract Res Clin Haematol 2017;30:109-17.

45. Wündisch T, Thiede C, Morgner A, Dempfle A, Günther A, Liu H, et al. Long-term follow-up of gastric MALT lymphoma after Helicobacter pylori eradication. J Clin Oncol 2005;23:8018-24.
46. Urakami Y, Sano T, Begum S, Endo H, Kawamata H, Oki Y. Endoscopic characteristics of low-grade gastric mucosaassociated lymphoid tissue lymphoma after eradication of Helicobacter pylori. J Gastroenterol Hepatol 2000;15:1113-9.

47. Ono S, Kato M, Ono Y, Nakagawa M, Shimizu Y, Asaka M. Magnified endoscopic images of gastric MALT lymphoma before and after treatment. Endoscopy 2007;39(Suppl 1):E328.

48. Ishihara R, Tatsuta M, Iishi H, Uedo N, Narahara H, Ishiguro S. Usefulness of endoscopic appearance for choosing a biopsy target site and determining complete remission of primary gastric lymphoma of mucosa-associated lymphoid tissue after eradication of Helicobacter pylori infection. Am J Gastroenterol 2002;97:772-4.

49. Palmela C, Fonseca C, Faria R, Baptista RB, Ribeiro S, Ferreira AO. Increased risk for metachronous gastric adenocarcinoma following gastric MALT lymphoma-A US population-based study. United European Gastroenterol J 2017;5:473-8. 